\title{
Spatial semiosis in culture
}

\author{
Leonid Tchertov \\ Dept. of Pilosophy, Saint-Petersburg State University, \\ Mendeleevskaja line 5, St. Petersburg 199034, Russia \\ e-mail: tcher@LC9661.spb.edu
}

\begin{abstract}
Lotman's conception of semiosphere opens the way to development of spatial semiotics as a special branch of sign theory. There are a lot of peculiarities in the spatial semiosis, which distinguish it from the temporal ones. These distinctions are connected with some special features of semiotized space, and they touch both upon the spatial texts and upon the spatial codes. The spatial syntax has its own specific structures, which can be reversed, non-linear and continual, created without discrete signs. The differentiation relates also to semantics of spatial signs and texts, which are mainly motivated by their denotates due to similarity or contiguity. There are some pragmatic peculiarities of the spatial semiosis: the greater connection with the praxis, on the one hand, and the greater ability for the preservation of the cultural memory, on the other hand. The mainly visual character of spatial texts in plane of expression can be also considered as its specific pragmatic property. These peculiarities give some special possibilities for the spatial semiosis and make necessary its participation in the various spheres of the culture, where diverse spatial codes interact in different ways between each other and with temporal codes as well.
\end{abstract}

\section{The problem of particularity of spatial semiosis}

The communication, which uses a space as its medium, is still not sufficiently investigated part of the semiotics. It has many specific features, a lot of them were noticed by Juri Lotman. The view of the scholar on the relationships between the verbal language and the spatial means of communication was changing in the development of his semiotic conception. The initial thought on a difference of the "primary" and the "secondary" sign systems was transformed into the conception of "semiosphere", where the interaction of minimum two types sign systems is necessary (see, particularly, Lotman 1992: 29- 
31, 53-54). Systems like the verbal language, which combine discrete conventional signs, need in principle other semiotic systems as their complement. These complementary systems control the creation of continual texts without separate signs, and they tend to deal mainly with iconic and other forms of motivated signs. Both types of the systems mutually need each other as in culture as in consciousness, and they can equally be considered as the "primary" sign systems (see Lotman 1992: 11-24, 142-147).

Thus, as Juri Lotman has shown, there is an essentially other kind of semiosis, than semiosis of linguistic type. Its properties are presented most clearly in the sign systems, where the plane of expression is built by visible spatial forms and their relations. As it was repeatedly pointed out, the spatial canal of information is connected with visual perception, like the temporal canal is connected with hearing (see Jakobson 1972). So the peculiarities of the spatial semiosis are dependent on the properties of both the external structures of spatial objects and their internal reconstruction in visual perception. Both of them are the components of the joint visual-spatial information canal.

The specific topological peculiarities of spatial objects - their non-linearity, reversibility, diversity of relations between symmetry and asymmetry etc. - influence the abilities to create the specific structures in the plane of expression, like the linearity and nonreversibility of time influence the particular frames of speech chains. The tree-dimensionality of the spatial canal gives a possibility to build the syntactic structures in more various configurations. That is not only quantitative, but also qualitative difference, because it allows to appear some additional kinds of meaningful relations between the dimensions. The space thereby can be anisotropic in a different way and has diverse classes of symmetry. The symmetrical constructions are as natural in spatial semiosis as they are unnatural for the temporal ones (where, for example, the palindromes are exceptionally rare). Further, because the spatial structures are formed by relations of coexistence and have some stability in temporal stream, they can be reversible and allow both forward and backward order in relations of their significant elements. The continuity of space can play its role as well, because the visual-spatial canal gives more possibilities for the continual picture of a whole, where is not easily to find some discrete parts (which was also not once noted by semioticians - see Ivanov 1976: 138; Lotman 1992: 31; Ivanov et al. 1998: 13-15, 38-40). Therefore the spatial semiosis allows syntactic structures to be built in 
an essentially other way, than the successive ordered chains of discrete signs, known for linguistics.

Specific properties of spatial semiosis depend not only on the external part of the visual-spatial canal, but also on the internal one on the peculiarities of visual perception. Its simultaneous character gives to eyesight the ability to take in the diversity of relationships between the objects as a whole picture, which disappears by translating in the successive row of signs (see Arnheim 1974: 92-93). This whole impression received from all the complex of spatial relations precedes the dividing into separate parts - in contrast to the acoustic perception of successive signals, where the choice of parts precedes the taking in of the whole. The difference between the successive perception of the speech constructions and the simultaneous synthesis in the visual perception correlates with the ability of spatial syntactic structures be formed not only as a combination of the ready units, but also as a result of the reverse process of dividing of a continual whole into separate parts with its subsequent differentiation (for example, in pictures and related forms of representation).

The ways of semiotizing of space have also some peculiarities in the plane of contents. The sphere of meanings, which are communicated by visual-spatial forms, includes both verbal and non-verbal levels of psyche, and the lasts play their irreplaceable role in the activity of mind - what was repeatedly accented by Juri Lotman (see, particularly, Lotman 1992: 46-57, Lotman 1996: 296). The Lotman's ideas on an interacting of two types of semiotic systems in the processes of thinking are accorded not only with the investigations of neurophysiologists on a functional asymmetry of right and left hemispheres of the brain (for example Nikolaenko, Deglin 1984), but also with the conceptions of the psychologists, who consider the activity of thinking as a process of mutual overcoding of information from nonverbal simultaneous form to the successive verbal one and backward (see, particularly: Zhinkin 1964: 36; Vecker 1976: 134). The universality of this mechanism appear, particularly, even in formation of logical-grammatical constructions in the verbal speech, which cannot be build without using any spatial images. The disturbing of brain structures, responsible for its creation, lead to the loss of ability to construct the propositions and to understand the logical relations (see: Luria 1979: 184, 197-198). It is clear, that the thinking need using of the spatial schemes, because they give other possibilities, than the successive rows of signs. 


\section{The semiotization of space and the spatial codes}

However, the peculiarities of spatial-visual canal of communication give only the general conditions to syntactic, semantic and pragmatic dimensions of the spatial semiosis. The opportunities of this canal can be used in a different way. The physical existence of spatial sign vehicles, as well as the psychical systems of their perceptions and understanding are just the components the "substance of expression" (in terms of Hjelmslev 1961). It is not enough also to analyse a "substance of contents", which depends on the way of interpretation of spatial message in the frame of some sphere of culture. They open some specific possibilities for building of spatial signs structures, but they do not necessarily determine a semiotic "form" of spatial expression. The internal semiotic aspects of spatial communication are related to ways of organisation of connections between that, what in Hjelmslev's terms must be cold as "form of expression" and "form of contents". Only the presence of semiotic "form" allows separating the meaningful spatial relations from the other, non-relevant, spatial and temporal ones, as well as to distinguish between diverse types of significant spatial structures.

The own semiotic properties of meaningful spatial objects depend on a definite way of structuring and of interpreting of space, i. e. - on the fixed way of its semiotization. The semiotization of space is just the same act, which brings a definite semiotic "form" into a "substance" of some spatial carriers. Each of the ways determines in its own manner picking out of meaningful spatial elements and their structuring, its own norms of interpretation, and its own conditions of their use by interpreters. These, correspondingly, syntactic, semantic and pragmatic rules establish together a spatial code - a semiotic system, which regulates the acts of coding and decoding of information in the visual-spatial canal (cf. Morris 1983: 67-68).

There are different systems of semiotization of space and, thereby, the spatial semiosis is realised not through one only "language of space", but due to several diverse spatial codes. These codes use various psychological and semiotic mechanisms and establish different norms of interpretation and behaviour in the space (see more detailed: Tchertov 1997). Accordingly, the semiotized by these codes space can get different forms. It can appear as a "power field", by the means of an architectonic code, correlating visual spatial forms with feelings of mechanical forces. It can be treated as a space of instru- 
mental actions, if it is semiotized with an object-functional code, which fixes the stable connections between constantly reproduced forms of the objects and its instrumental functions. It can be structured and interpreted also as a space of social behaviour, if its semiotization is regulated by a social-symbolic code, which correlates spatial relations of objects with social characteristics of subjects. The space of depiction appears due to using of a perceptographic code, which mediates a translation of some optical marks into a perceptual image of the visible world. The space of written text is subordinate to diverse systems of writing etc.

Some certain part of space, which is semiotized as a result of using one or more spatial codes, can be considered as a spatial text (cf. Toporov 1983). Any spatial text includes only the spatial relations, which are connected with the function to express the meanings according a system of code. So, the spatial codes and regulated by them texts are mutually connected, like the language and speech in linguistics. But the peculiarities of the spatial ways of the sense expression put own imprint on the spatial codes, and therefore the linguistic models are not very effective for analysis of many kinds of spatial texts.

The spatial texts subordinated to diverse codes can have a specific syntax with particular topological properties. For example, the space of a picture is non-linear, reversible and continuous in contrast with spatial structure of the one-dimensional, irreversible and discrete written text. Therefore, the description of spatial syntax needs working out its own theoretic models. These models can become the subject of a special part of spatial semiotics - of "semiotopology", which would be aimed at the research of topological properties of syntactic structures in spatial texts: discreteness and continuity, openness and closeness, homogeneity and heterogeneity, dimensionality and so on. These properties are important for semiotopology only as semiotic qualities - to the extent to which they are necessary for semantic and syntax and belong to the "form of expression" but not to its "substance". So, the semiotopology deals only with the meaningful structures of spatial texts, but not with the topology of physical carriers of information or of their mental images.

The semiotization of space establish together with its external structuring also its reverse side - the internal ordering of mental schemes, which regulate the ways of the perception and understanding of the spatial objects. Both the external arrangement of space and its internal frame are subordinated to spatial schemes, which are es- 
tablished by a spatial code. So the cultural space is a product of the exteriorising of internal spatial schemes as well as these schemes are worked out in the result of interiorising of external spatial activity.

The interpretation of spatial relations from these schemes performs due to semantic units, which form the plane of contents of some spatial codes. These semantic units can be not the logical concepts and have other "psychological addresses". They may belong to diverse psychical levels: sensory, perceptual, apperceptual, conceptual, as well as to various motor and affective structures. For example, the objectfunctional code develops in the practice of instrumental activity as a parallel to verbal language, and it has in plane of contents instead the verbal meanings the "practical concepts" (in J. Piaget's terms) - the motor schemes of instrumental actions.

\section{Genetic, functional and structural peculiarities of spatial codes}

The spatial codes as semiotic systems have own peculiarities, which touch their origin, functions and structures. All of them are used in some way in culture, but many of them have still a natural genesis, which is independent of speech, and go back to biologic signal systems. So, not all of spatial codes relate to the verbal language as the "secondary" sign systems, and several of them, on the contrary, serve as conditions of ability to create complicated constructions in verbal syntax and in logical thinking. These codes are involved in the semiosphere of culture in another way, than the verbal language and similar systems. While the verbal language was formed in culture initially as a system of external communicative means between the subjects, the spatial codes were developed above all in the processes of subject-object activity (cognitive and projective) as an internal psychical regulator of human behaviour. Accordingly, while speech becomes the internal means of mind due to interiorization of intersubjective communicative actions, these spatial codes are the cognitive means initially, and they get their communicative function in the opposite process of exteriorisation, where the mental actions are expressed through the outside spatial forms (cf. Vygotsky 1982: 356).

For example, the perceptual code has been originated as a cognitive system of visual decoding of optical signals. But its naturally formed means were reflected and exteriorized in the practice of 
pictorial communication. So the culture reformed the intrasubjective perceptual code into its diverse intersubjective versions, each of them can be called as a "perceptographic" code. Another type of the natural codes - the synesthetic ones - serves as a basis for the architectonic code, which have been created in culture also as a result of the process of reflection and exteriorization of synesthetic and kinesthetic signals. In a similar way the means of natural mimic and pantomimic codes becomes in culture consciously and freely reproduced.

This role of spatial codes is connected also with specificity of their functions. Like the temporal means of communication, the spatial semiosis performs the functions of representation, of communication and of thinking, but in another way. The representative function can be performed, for example, due to iconic spatial models, which reproduce their objects in praesentia of text, but not in potentia of any semiotic system - in contrast with the language, where just the potential paradigmatics mainly realized the modeling function.

The peculiarity of communicative function in spatial semiosis is determined by its ability to connect the subjects, who belong to diverse moments of time - in the contrast to participants of verbal dialog, who are united by one temporal moment. If the moment of time joints all, what is "there" and "now", the space joints the moments "here" and "then"; so the space unites diverse temporal moments as well as it joints subjects, separated through temporal distance, whereas the time connects points, distanced in the space.

Many of spatial codes, like the verbal language, are able to serve not only as the means of the external communication but also as the tools of the internal processes of thinking. The function of thinking is performed due to means of the spatial codes on the other "floors" of the psyche, than the level of logical concepts. The visual or moving schemes of spatial thinking belong to non-verbal levels of psyche and to not theoretical, but practical intellect. However, as already was marked, the most abstract levels of thinking cannot function without the spatial images. The ability to build the synthetic mental picture allows to spatial thinking on all its levels more easy to grasp a whole.

The genetic and functional peculiarities of the spatial codes influence also some their structural particularities. While the acoustic signal systems tend to provide the maximum effect with the minimum length of the text in the time, the visual-spatial systems can mediate the decoding of information in another way. For example, the iconic spatial models serve not as a key for opening of the thesaurus full of collected knowledge, but they carry the main information in its own 
structure. It is this structure of the text that mainly performs the model function, unlike the sign systems of verbal type, where the model function is performed rather by an implicit system of a code, than by an explicit text. Therefore the latter type of semiotic systems needs a preliminary "dictionary" of signs with ready meanings, whereas the former does not need it, and many of spatial codes have neither dictionary nor alphabetic units. Some of these codes belong to "grammatical", but not to "lexical" type of language (in F. de Saussure's terms). For example the system of linear perspective gives the principle of arrangement of visual indices of depth on a plate - a system of shortenings - and can be considered as an important part of a perceptographic code. However, neither the perspective, nor the perceptographic code as a whole do not have any "dictionary" of ready signs. Unlike the verbal language, their implicit structure gives a very poor model of space, whereas the explicit syntagmatic structure of the picture, built with their help, models a certain space much fuller than any verbal text.

Instead of an alphabet of discrete signs some of the spatial codes have continual fields of forms and colours. The sense-discriminating elements in these systems are subordinate not to "the principle of alphabet", but to "the principle of palette" (see Tchertov 1996). The latter allows mixing the elements in diverse ways, like the palette giving opportunities for various mixing of colours. Thus, instead of the controversy between "yes" and "no", the palette establishes a gradual flowing of sense-discriminating elements one into another according to the principle "more" or "less" (cf. Eco 1976: 176). Thereby the "principle of a palette", contrary to the "principle of an alphabet", allows to operate not only with contrasts of binary oppositions but also with nuances. This principle more correlates with the continuity of space, as well as with its non-linearity and reversibility - whereas the "alphabetic principle" is correlated with onedimensionality and irreversibility of verbal texts. If the last principle makes possible the successive selection of discrete signs in time and their joining on the "axis of combination" (in Roman Jakobson's terms), the principle of palette is more relevant for simultaneous synthesis of many relations in a united whole, grasped before its separate parts are distinguished. This principle is valid for colours as well as for figures, and not only in the frames of the perceptographic code, but also of the architectonic or of social-symbolic codes. 


\section{Spatial semiosis as part of semiosphere}

The ability of spatial codes functioning as the means of communication, representation and thinking lets them, along with the verbal language, be an important part of the semiosphere. These codes are included in different area of culture mediating in heterogeneous relations of the human towards the nature and society. But the structural and the functional peculiarities of spatial semiosis let it play a particular role in the semiosphere of culture.

A space is not only a medium of communication between the subjects, but above all an environment of their activity: moving, working etc. This environment consists of multitude of manifold areas and forms, which also can be considered as various syntactical and semantic types of spatial texts. A home, a street, a city etc. can be considered as different types of spatial text, regulated by different norms of space semiotization. These texts serve first of all as the means of regulating of a human behaviour - instrumental and social. There are also the separated spatial texts, which are intended special for communicative function (writings, paintings etc.). The latter are combined together with the former in a complex spatial hypertext. An example of such a complicated space was given by Juri Lotman as an illustration of his idea of "semiosphere": a museum hall, "where the exhibits of various ages are presented, together with writings in known and unknown languages, instructions on its decoding, the texts, explaining the exhibition, schemes of excursion routs and rules of visitors behaviour" (Lotman 1992: 53-54). The transit from one type of spatial text and its ways of semiotization to another is regulated with the help of special markers, which point out to the switching from one code to the other, and so function as indices of a spatial metalanguage. It is possible also, that the same spatial locus is semiotized by different ways and can contain spatial texts regulated by several codes. Then these codes can enter into various relations and between each other: to complement or to except one another, to be in crossing and excluding, coordination or subordination etc. The interaction of these codes in the various forms may be a subject of some "visual rhetoric", which appears where different codes take part together in making up some complex text with a total sense (cf. Lotman 1998: 611).

The spatial codes interact also with the temporal sign systems like the verbal language. The divergence of organization gives various opportunities for their interaction. There is a possibility to change the 
audio-temporal plane of expression into the visual-spatial one - due to its new coding (as in phonetic writing) or due to its translation (as in ideography). In both cases the spatial elements and structures are subordinate to linguistic forms. However, if the spatial way of representation retains its own features, it is rather a re-organisation of some contents from the verbal speech into visual form, than a translation of them. A spatial way of expression allows to transpose paradigmatic structures of the language and of its secondary systems into syntagmatic constructions. The non-linearity of spatial texts provides a possibility to present for a vision some whole structures, which are given in the verbal language only implicitly. For example, iconpainting, which had to translate gospel narration into visual form, makes something different. Through the oppositions of top and bottom, left and right etc. it has opened for visual perception some hierarchic and value relations, which are only implied in the verbal narration, but are not explicitly presented in it. Generally, the spatial codes give also a visual basis for the development of invisible structures in diverse systems of culture: language, myth, religion etc. (cf. Cassirer 1923: 147-166; 1925: 107-132).

The spatial codes and texts arranged by them are very important for the sphere of art. The peculiarity of arts is not in the use of some special "languages of art", but, on the contrary, in the involving into them and in the special working out of codes, used also in many other spheres of culture. Like the arts of word organise the signs of everyday language in a special way giving them an artistic effect, the spatial arts work out the means of the everyday spatial codes. The semiotic means of these ordinary codes are arranged and rearranged in works of art being transformed into the means of artistic expression. For example, the figurative art can be considered as the art of exteriorizing the diverse means of the cognitive perceptual code, which are selected and reflected by artists, and turned out into the means of communicative "perceptographic" code.

Various kinds of arts are distinguished from each other due to the complexes of semiotic means being worked out by them. Although there is a dominating code for every kind of spatial art, each of them deals as a rule with several codes. So architecture deals not only with the means of architectonic code, but also with the means of socialsymbolic and object-functional codes, as well as the representative arts work out the means of the different versions of perceptographic code together with some other spatial codes: object-functional, mimic, pantomimic etc. 


\section{Spatial semiotics as an autonomous branch of sign theory}

Thus, it is natural to suppose that the spatial semiosis can be the subject of a special branch of semiotics. It deals with the ways and the results of semiotization of space, i. e. - with the spatial codes and the spatial texts. The semiotics of space has to find its relations to other semiotic disciplines and, first of all, - its place in the system of general semiotics (what is important for least too). Particularly, it have to definite, on one hand, some common properties with others semiotic systems and, on the other hand, - some peculiarities, what separates it from them.

The spatial semiosis, as any ones, can certainly be described in the general categories of Peirce's and Morris' semiotics, which considers signs in syntactical, semantic and pragmatic dimensions. It can be described as well in some concepts of Sausurean semiology, which considers correlation between signifiant and signifié in whole sign systems, in oppositions of system and text, paradigmatical and syntagmatical aspects, synchrony and diachrony, etc.

But the analogies of spatial semiosis with other sign systems have the limits, beyond which its principial distinctions begin. The difference between spatial and temporal order of sign vehicles in diverse kindes of art is a subject of discussions, which are well known at least since Lessing's time (see Lessing 1957: 187). This subject is important not only for aesthetics, but for semiotics too. The spatial semiotics has to define its place in relationships to other, non-spatial, spheres of semiotic investigations. There are the grounds to consider the semiotic of space as a separate branch of semiotics, correlated with the temporal semiotics, presented first of all by the Saussurean semiology. The semiology of Saussure and of his followers appears in this relationship as a "chronosemiotics" - semiotics of temporal chains. In particular, the both main principles of the language, which Saussure had suggested - i.e. non-motivated semantic links of signs with its meaning and their linear order in plane of syntax - are non-valid for most of spatial codes and thereby not much applicable to description of spatial semiosis. So, the initial principles of his semiology — the principle of lineal ordering of significants - is the direct consequence of successive interchange of accustic signals in the time, and, as Saussure pointed out, the "whole mechanism of language" depends on this temporal order of signs (Saussure 1977: 103). Already this is enough 
for a consideration of saussurean semiology as a "semiology of time", which needs the "semiology of space" as a parallel branch to be added. Also the other principle of Saussurean semiology — the arbitrariness of signs - is not relevant for the spatial semiosis. On the contrary, the last opens the most rich possibilities for variously motivated means of diverse spatial codes and, particularly, - more possibilities for iconic representation of objects.

Thus, the semiotic of space as an autonomous branch of sign theory cannot be described by a mechanical projection on the meaningful spatial objects of theoretical models, elaborated in linguistics or in temporal oriented semiology. Wereas its mechanisms depend on the temporal canal of communication, "all mechanism" of the spatial semiosis correlates with the possibilities given by spatial canal of communication and by its simultaneous perception. So far as the general semiology was being developed in a search of some analogies between the verbal language and other sign systems, so the particularity of temporal semiotics could remain unnoticed. But the more the spatial semiotics develops and its specific features are recognised, the more it gets the shape as a parallel branch of the sign theory, which deals with principally different ways of semiotization.

\section{References}

Arnheim, Rudolf 1974. Art and Visual Perception. 2th ed. Berkeley: University of California Press.

Bruner, Jerome 1984 [1975] = Брунер, Дж. Онтогенез речевых актов. In: Шахнарович, А. М. (сост), Психолингвистика. Москва: Прогресс, 21-49.

Cassirer, Ernst 1925. Philosophie der symbolischen Formen. Berlin: Bruno Cassirer Verlag.

Eco, Umberto 1976. A Theory of Semiotics. Bloomington: Indiana University Press.

Hjelmslev, Louis 1961. Prolegomena to a Theory of Language. Madison: University of Wisconsin Press.

Ivanov, Vjacheslav V. $1976=$ Иванов, В. В. Очерки по истории семиотики 6 СССР. Москва: Наука.

Ivanov, V. V.; Lotman, J. M.; Pjatigorski, A. M.; Toporov, V. N.; Uspenskij, B. A. 1998. Theses on the Semiotic Study of Cultures. (Tartu Semiotics Library 1.) Tartu: Tartu University Press.

Jakobson, Roman 1972 [1964] = Якобсон, Р. О. К вопросу о зрительных и слуховых знаках. In: Лотман, Ю. М.; Петров, В. М. (сост), Семиотика и искусствометрия. Москва: Мир, 82-87. 
Lessing 1957 = Лессинг, Г. Э. Лаокоон, или О границах живописи и поэзии. Москва: Гос. изд-во худож. лит-ры.

Lotman, Juri 1992 = Лотман, Ю. М. Избранные статьи. Т. 1. Статьи по семиотике и типологии культуры. Таллинн: Александра.

- 1996 [1990] = Лотман, Ю. М. Внутри мыслящих миров: Человек текст - семиосфера - история. Москва: Языки русской культуры.

- 1998 = Лотман, Ю. М. Театральный язык и живопись (К проблеме иконической риторики). In: Лотман, Ю. М. Об искусстве. СПб: Искусство, 608-617.

Luria, Alexander R. 1979 = Лурия, А. Р. Язык и сознание. Москва: Изд-во МГУ.

Morris, Charles W. 1983 [1938] = Моррис, Ч. Основания теории знаков. In: Степанов, Ю. (ред.), Семиотика. Москва: Радуга, 37-89.

Nikolaenko, N. N., Deglin, V. L. 1984 = Николаенко, Н. Н.; Деглин, В. Л. Семиотика пространства и функциональная асимметрия мозга. Tpydbl no знаковьи системам (Sign Systems Studies) 17: 48-67.

Saussure, Ferdinand de 1977 [1916] = Соссюр, Ф. де. Курс общей лингвистики. In: Соссюр, Ф. де, Труды по языкознанию. Москва: Прогресс, 31269.

Tchertov, Leonid F. 1996 = Чертов, Л. Ф. “Алфавит" и "палитра": два принципа смыслоразличения. Silentium 3: 422-428.

- 1997. The semiotization of space and dynamic codes. Semiotica 114(3/4): 287-293.

Toporov, Vladimir N. 1983 = Топоров, В. Н. Пространство и текст. In: Тексm: семантика и структура. Москва: Наука, 227-285.

Vecker, Lev M. 1976 = Веккер, Л. М. Психические процессы. Т. 2. Мышление и интеллект. Ленинград: Изд-во ЛГУ.

Vygotsky, Lev S. 1982 = Выготский, Л. С. Мьишление и речь. Собрание сочинений. Т. 2. Москва.

Zhinkin, Nikolay I. 1964 = Жинкин, Н. И. О кодовых переходах во внутренней речи. Вопросы языкознания 6: 26-38.

\section{Пространственный семиозис в культуре}

Лотмановское понимание семиосферы и роли в нем пространственных способов смысловыражения открывает путь для развития пространственной семиотики как особой ветви теории знаков. В отличие от речи и подобных ей временных последовательностей знаков, пространственный семиозис имеет ряд особенностей, которые сказываются на структуре и функциях участвующих в нем знаковых систем и на свойствах построенных с их помощью пространственных текстов. Последние могут, в частности, иметь синтаксические структуры, обладающие такими свойствами, как обратимость, не-одномерность и непрерывность, связанная с отсутствием априори заданных дискретных знаков. Подобные свойства становятся предметом для особого раздела семиотики 
пространства - семиотопологии, исследующей их соотношения в различных типах пространственных текстов. Особенности пространственного семиозиса затрагивают и семантику пространственных знаков и текстов, которые, как правило, в большей мере связаны со своим денотатом отношениями сходства или смежности. Свои особенности имеют и прагматические свойства пространственного семиозиса, важнейшим из которых можно считать преимущественно визуальный характер пространственных текстов в плане выражения. Особенности пространственного семиозиса делают необходимым его участие в различных сферах культуры, где разные пространственные коды взаимодействуют различным образом друг с другом и с временными кодами.

\section{Ruumiline semioos kultuuris}

Lotmani arusaam semiosfäärist ja mõtteväljenduse ruumiliste viiside osast selles avab meile tee ruumisemiootika kui märgiteooria eriosa arendamiseks. Erinevalt kõnest ja sellega sarnastest ajalistest märgijärgnevustest on ruumilisel semioosil rida eripärasid, mis kajastuvad selles osalevate märgisüsteemide struktuuris ja funktsioonides ning nende abil loodud ruumiliste tekstide omadustes. Ruumilised tekstid võivad näiteks omada süntaktilisi struktuure, mida iseloomustavad pööratavus, mitmemõõtmelisus ja pidevus, mis on seotud $a$ priori antud diskreetsete märkide puudumisega. Taolised omadused saavad ruumisemiootika ühe osa - semiotopoloogia — osaks, mis uurib nende seoseid ruumiliste tekstide erinevates tüüpides. Ruumilise semioosi iseärasused puudutavad ka ruumiliste märkide ja tekstide semantikat, mis reeglina on oma denotaadiga seotud sarnasuse ja külgnevuse suhte kaudu. Omad iseärasused on ka ruumilise semioosi pragmaatilistel omadustel, milledest tähtsaimaks tuleks pidada ruumiliste tekstide peamiselt visuaalset iseloomu väljendusplaanis. Ruumilise semioosi iseärasused teevad vajalikuks tema osaluse erinevates kultuuri sfäärides, kus erinevad ruumilised koodid erineval moel suhestuvad üksteise ja ajaliste koodidega. 